$P-489$ 前立腺全摘除症例の臨床診断（主に6 分割法前立腺 生検、PSA 值) 之病理組䅧学的検討

聖路加国際病院 永田幹男、貫井文彦、黄 英茂、黒川 純、 福井準之助、岡本重禮

【目的】前立腺全摘除術前に進行癌の可能性を判断するのに6 分 割法前立腺生検及び PSA 值が有効か検討した。

【方法】臨床診断と術後病理組織診断について、6 分割法により 発見された前立腺癌で前立腺全摘除術症例 27 例中 neoadjuvant therapy 症例 4 例之pT 1 b 症例 1 例は除く 22 例を含む 94 例の PSA 值と生検陽性率、手術症例 22 例の PSA 值と左右各々の陽 性摔を検討した。

【結果】1）生検陽性率が高いほど臨床診断Stage Dの占める率 が高い。

2) 前立腺全摘除術症例中 8 例が術後病理組織診断でpT3の進行 癌である。このうち5症例は 6 分割法生検で左右の一方が $100 \%$ 陽性である。

3) 手術症例の細胞異型度は進行癌( pT3)で低分化型は $50 \%$ (4/8例)、限局性癌は $21.4 \%$ ( $3 / 14$ 例)である。

4) 手術症例で PSA 值 $20.1 \mathrm{ng} / \mathrm{ml}$ 以上の進行癌は $50 \%$ ( $4 / 8$ 例)、限局性癌は $7.1 \%(1 / 14$ 例)である。

【結語】術前診断で限局性癌上診断したが、術後進行癌であった 症例は $36.4 \%(8 / 22$ 例 $)$ である。術前限局性癌と診断しても6 分 割法前立腺生検で左右一方が $100 \%$ 陽性例、PSA 值 $20.1 \mathrm{ng} / \mathrm{ml}$ 以上の症例は進行癌の可能性が高い。

\section{$P-491$}

$\mathrm{T} 1 \mathrm{c}$ 前立腺癌の盬床的検討

带広厚生

丸山覚·山下孝典・谷口明久 ·間宮政喜 ·坂下茂夫

【目的】前立腺検診で血清PSA 高值により診断される T1c前 立腺癌が増加しているが、その臨床像および組織像を検討し た。

【対象と方法】1994年1月より1997年8月までに恥骨後式前 立腺全摘除術を施行した前立腺癌 65 例の臨床病期は、 $\mathrm{T} 1 \mathrm{~b}$ 8例、T $1 \mathrm{c}-16$ 例、T 2-37例、T3-4例であった。T1c症例 の術前組織診断は超音波ガイド下経直腸的 six sextant needle biopsyによりなされた。血清PSA測定はアボット社の $\mathrm{IMx}$ により測定したが、その測定感度は $0.1 \mathrm{ng} / \mathrm{ml} ゙$ ある。摘 除前立腺は $5 \mathrm{~mm}$ 間隔の全割標本とし、組織学的分類および pT分類を行った。腫瘍体積をD'Amicoの方法により算出した。 【結果】T2例では針生検前の血清PSA值は、37例中 24 例で $10 \mathrm{ng} / \mathrm{ml}$ 以上の高値を示したが、T1c例の血清PSAの平均(範 用）は10.7（4.8～18）ng/mlであり、T2例に比べ低值であ った。摘除標本の Gleason sum の平均はT3例では6.5、T2例 では5.3であるのに対して、T1c例は3.6と低值であった。し かし、腫場体積はT2とT1c例の間には差はなく、また $\mathrm{pT}$ 分 類ではT1c症例16例中13例がpT3であった。

【考察】どのような病期の前立腺癌が根治手術のよい適応か は議論のあるところである。T1cは血清PSAのみ高値で触知 不能の前立腺癌であるが、腫境体積やpT病期からは手術適 応のある癌と考えられた。したがって、gray zone（4〜 $10 \mathrm{ng} / \mathrm{ml})$ 症例を含めたPSA高值症例に対して、積極的な生 検によりT1c 前立腺癌を診断することには意義があると考え られた。

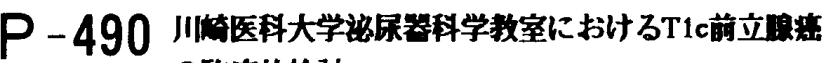 の殹床的俆郡}

川崎医科大学

新海正典·松木孝和 ·常 義政·絹川敬吾·森岡政明·田中繁幹

目的) 最近，PSAの上昇によってのみ診断されるT1c前立腺哮が とりさたされているが, その臨床における位員付けはなお一定し ていない。今回我々は当科におけるT1c恣について報告する。

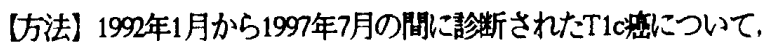
病理学的特徴を中心に检討した。なおT10疾の定義は，DREと経直 腸的超音波で異常なかったが，PSA (Tandem-R) $4.0 \mathrm{ng} / \mathrm{ml}$ 以上に对 し行ったSystematic biopsyで初険出されたものとした。

【結果】この期間中に13例のT1c前立腺淲が診断された。診断時の PSA值は7.6〜29.3 ng/ml（中央值:11.9）だった。13例のうち前立腺 全摘除術が例に施行され, 病理学的にはMAB瘖法にてneoadjuvan

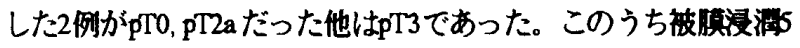
例, 多中心発生は4例に認められた。

【考察】T1c虫はPSAの上界のみによって診断されてくる度で、早 期痓の可能性が高いことが想像されるが，害際には病理組䋨診断

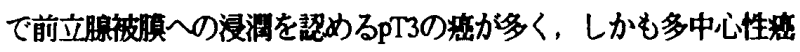
か高頻度に認められた。今後症例の皘み重ねによりその生物学的 特徽を検討することが必要である。現在のPSAとSystematic biopsy を 組み合わせた診断方法では前立腺旗の10\%弱を占める。これらT1c

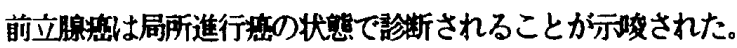

\title{
$P-492$ 前立腺癌の年歯と病期、病理の関係
}

群馬大学" 1 熱川温泉病院 ${ }^{1}$

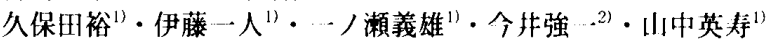

群馬大学グループ泌怺器科腫場研究会

【目的】前立腺癌における年齢と病期、病理組織との関係を調

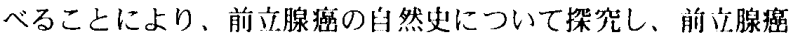
検診の検衫方法への応用を検討した。

【対象抢よび方法】群馬罧における1981年〜 1996年の前站腺 癌登録のうち、外来群 2493 名、検診群 285 名を对象とし、年齢 による病期や病理の変化の有無について调查した。

【結果】外来群では加柃による病期の変化は認められなかった。 検診群において、加齢により進行癌の割合が多くなる傾问が認 められた。各病期stage B，C，Dの平均作㱓は71.0，73.9，74.5 歳であった。病理組織と年齢との関係では、外来群、検診群と もに有意差は認められなかった。

【結語】検㟝において加齢により病期は進行する傾向が認めら れた。以上より、早期煰は約 3 年で進行癌となり、その半年〜 1 年後に転移をきたすモデルが考えられた。このモデルから推測 される前立腺癌検診の受診間隔は2年程度がよいと思われた。

Stage distribution by Age at Dignosis in Mass Screening

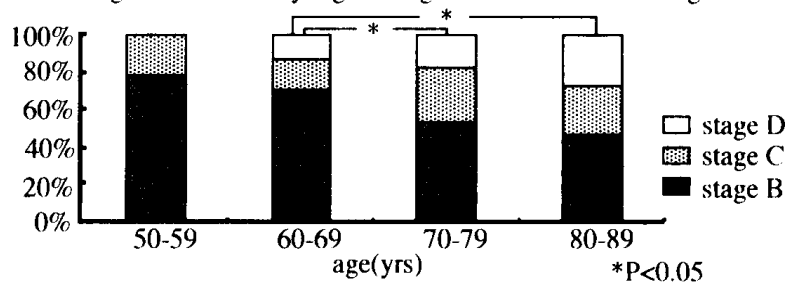

